\title{
Generation J
}

In late April 2013, The Economist carried a leader and a substantial article on 'Generation jobless'1. The International Labour Organization estimates that at least 75 million young people (15-24 year olds) worldwide are job seekers, while the World Bank believes that 262 million young people are economically inactive in emerging market countries - with the total figure for the world being closer to 300 million. At the global level, ongoing economic woes are probably the greatest single cause of joblessness, although additional, specific factors apply in particular countries. So while the obvious starting point in creating youth employment is to restart economic growth and ensure that well-organised and supportive labour markets are operating effectively, countries need to consider their own circumstances with care.

South Africa's Centre for Higher Education Transformation (CHET) revealed in a 2009 publication $^{2}$ that, in 2007, there were 2.7 million young people in the local 18-24-year-old cohort who were not in employment, education or training (NEET). By 2011 this figure had grown to 3.2 million $^{3}$ or about $40 \%$ of the cohort and more than three times the number of young people in South African public and private universities (about 950000 students). Addressing the dire circumstances of NEETs in South Africa requires far more rapid and consistent economic growth. But with year-on-year GDP in decline since the fourth quarter of 2010, and with opposition to the National Development Plan - a plan that might change the downward trend - this route is not, right now, an option. Sadly, job creation programmes for the young and unemployed have largely been resisted and, where they have come into being, have not touched the growing numbers of unemployed youth.

Other ways of addressing this potentially risky socio-economic situation are clearly needed. And amongst these, education is foremost - not just any education, but programmes directed towards the needs of NEETs that include a strong focus on science and technology, both theoretical and applied. Partly in response to the CHET findings, the Department of Higher Education and Training prepared and launched its Green Paper on Post-School Education and Training, aimed at addressing the problem, in January 2012, with a 3-month period for comment and response that ended on 30 April 2013.

During those 3 months, vast volumes of commentary were generated by, amongst others, the Council on Higher Education, Higher Education South Africa and most of the public universities. Many of the responses started with phrases such as the Council on Higher Education's comment: 'The release of the Green Paper on Post-School Education and Training signals a key shift in the evolution and development of the postapartheid transformation of the education and training system'. From there on, however, most of the commentary was critical of a document that lacked coherence and failed to address the real needs of young people, the education system and the economy. Twelve months on, there is still no sign of a White Paper - at a time when The Economist has seen good cause to highlight the serious challenge posed by 'Generation J' mentioning South Africa as a case in point.

Instead of a satisfactory outcome, what appears to be a parallel process has been underway. Well before the end of the period for public responses to the original Green Paper, a task team, also created by the Department of Higher Education and Training, submitted a report on 'Community Education and Training Centres and Community Colleges.' This report was made available to Minister Nzimande on 12 April 2012, and deals with a very specific recommendation in the Green Paper that such Centres and Colleges should be established. The task team's report was not made public, however, until October 2012 and, after the release of the report, a further 6 months passed before the Minster called for comment in the Government Gazette of 04 April 2013, with the commentary period set at 31 days. There is little to suggest that the report takes cognisance of any of the comments received on the Green Paper, although the report does set out, in much greater clarity, the need for Community Colleges and their role. In doing so, the report proposes a serious post-school option for school leavers in addition to universities.

The core of the report revolves, not surprisingly, around the creation of Community Learning Centres (CLCs) and Community Colleges. The CLCs, it is proposed, would provide basic and some general education for adults and young people in need of literacy and numeracy skills. There would be a CLC in every municipality. The Community Colleges would be similar to those in the USA and would, apart from their central teaching tasks, be required to provide a supportive role to the CLCs and create routes of articulation into higher education institutions - institutions that are already undertaking this work against a background of becoming overfull and less effective in fulfilling their own responsibilities. Nine in number - one in each province - the Colleges would, it is proposed, be specialist in nature - covering disciplinary clusters such as teaching, nursing, agriculture and technology. As this proposal would imply an overlap with university functions (in teaching, for example), both legislative and practical amendments would be required.

Most worryingly, while the Green Paper and the current education budget make it very clear that there will be no, or very limited, additional resources for the education sector (which already receives some $20 \%$ of the overall budget), the report proposes the creation of the CLCs and nine Community Colleges at considerable additional cost.

The task team's report proposes that it (the report) should be incorporated into the Green Paper (which may or may not be undergoing changes that will reflect the responses received a year ago) when it becomes the White Paper. And again, there is no guarantee that responses to the report will be heeded in any way.

Here, then, is the timeline: In 2009, CHET reported that 2.7 million young people between the ages of 18 and 24 were NEETs. The immensity of the problem was covered in the local and international press (including the New York Times). In 2011, the number of NEETs had grown to 3.2 million, by which time work was in progress on what was hoped would turn out to be a relevant Green Paper. Now, 4 years after the problem was identified and made public, nothing practical has been done by the Department of Higher Education and Training to implement current solutions. The numbers of NEETs continue to grow and there is nothing available to address the present problem. The solution proposed for the future will take, at best, many more months to finalise and a good number of years, and large sums of state funds, to implement.

So many years wasted; so many opportunities wasted. Time for the Ministry to focus more earnestly on the well-being of young people and the economy.

\section{References}

1. Generation Jobless. The Economist. 2013 Apr 27;49

2. Cloete N, editor. Responding to the educational needs of post-school youth: Determining the scope of the problem and developing a capacity-building model. Cape Town: CHET; 2009.

3. Perold H, Cloete N, Papier J, editors. Shaping the future of South Africa's youth: Rethinking post-school education and skills training. Cape Town: African Minds; 2012.

HOW TO CITE: Butler-Adam J. Generation J. S Afr J Sci. 2013;109(5/6), Art. \#a0021, 1 page. http://dx.doi.org/10.1590/sajs.2013/a0021 